\title{
Morphometric and meristic character variability and relationships among populations of Boops boops (L.) from four marine stations along the Tunisian coast
}

\author{
Mouna Ben Labidi, Hassen Allaya, Adel A. Basyouny Shahin, Jean-Pierre Quignard, \\ Monia Trabelsi, Abderraouf Ben Faleh
}

Received - 29 August 2020/Accepted - 13 March 2021. Published online: 31 March 2021; @Inland Fisheries Institute in Olsztyn, Poland Citation: Ben Labidi, M., Allaya, H., Shahin, A.A.B., Quignard, J.-P., Trabelsi, M., Ben Faleh, A. (2021). Morphometric and meristic character variability and relationships among populations of Boops boops (L.) from four marine stations along the Tunisian coast. Fisheries \& Aquatic Life 29(1), 13-28

\begin{abstract}
The variability of 14 morphometric and seven meristic characters of Boops boops (L.) collected at four stations along the Tunisian coast was examined in 518 samples ranging from 126 to $206 \mathrm{~mm}$ in total length and 37 to $78 \mathrm{~g}$ in total weight. Statistical analysis of both sets of characters showed significant variation among the four populations in $13(92.9 \%)$ morphometric and four (57.1\%) meristic characters. CVA and cluster analysis of the morphometric characters revealed four groups corresponding to four populations, with $95.36 \%$ correct classifications of individuals to their populations of origin. However, CVA and cluster analysis of the meristic characters showed a reticulate relationship among the four populations, as there was clear differentiation between those in Monastir and
\end{abstract}

M. Ben Labidi [ $\Xi^{\circ}$ ], H. Allaya, M. Trabelsi, A. Ben Faleh

Laboratory of Ecology, Biology and Physiology of Aquatic Organisms (LR/18/ES/41), Faculty of Sciences of Tunis, University of Tunis El

Manar, Tunis, Tunisia

E-mail: benlabidimouna@gmail.com

A.A.B. Shahin

Department of Zoology, Faculty of Science, Minia University, El

Minia, Egypt

J.-P.Quignard

Laboratoire d'ichtyologie, Université Montpellier П, P1. E. Bataillon, case 102, 34095 Montpellier cedex, France
Zarzis and an overlap between those in Bizerte and Kelibia, with only $51.75 \%$ of individuals correctly classified to their respective populations. This morphological differentiation among the populations from the four stations was attributed to the differences in the physico-chemical water properties at these stations. However, further studies are needed on the impact of environmental factors and diet at these stations on the morphological population structure of $B$. boops to better understand the contribution of environmental conditions to morphological variation.

Keywords: Boops boops, populations, relationship, morphometric characters, meristic characters, Tunisian marine stations

\section{Introduction}

Morphological or phenotypic variations among fish populations are controlled by a combination of environmental factors that include but are not limited to temperature, salinity, radiation, dissolved oxygen, water depth, and current flow (Lindsey 1988, Turan 2000). Phenotypic variations can include variation in morphometric and meristic characters that are 
dynamic characters commonly used to measure differences among populations of the same fish species (Ihssen et al. 1981, Cadrin 2000, Doherty and McCarthy 2004, Jayasankar et al. 2004) and have been used repeatedly to identify stocks of a variety of exploited fish species (Murta 2000, Silva 2003, O’Reilly and Horn 2004, Turan 2004). These phenotypic variations in morphometric and meristic characters among fish of the same species stem from differences in sex, food availability, predator-prey interactions, physical parameters, and environmental conditions (Dasgupta 1991). Morphometric relationships are used to determine minimum legal sizes in many developed countries for fisheries management (Thomas 1973).

Morphometric characters are continuous, quantifiable characters that describe features of body shape and size (Turan 1999). However, several morphometric characters reflect ecophenotypic variation and are commonly used not only in biometric studies as is common in field studies (Waldman 2005), but also in studies of species health and reproduction in the environment (Fagbuaro et al. 2015). On the other hand, meristic characters are several discrete, serially repeated, countable structures that are controlled in unknown proportions by genetic and environmental factors (Swain and Foote 1999, Liasko et al. 2012) and have also long been used for identifying fish stocks (Jawad et al. 2017, 2018) and providing information for subsequent studies on stock improvement (Jawad and Al-Janabi 2016). These characters are established during larval ontogenetic development and remain stable throughout the lives of fishes, i.e., they reflect environmental influences over a relatively short period of larval development (Jawad et al. 2017). As a result of these criteria, significant variations can occur within stocks among year populations or geographic subgroups exposed to changing environmental conditions (Silva 2003, Jayasankar et al. 2004). However, regular environmental influences have the potential to provide stock discrimination as there is little genetic variation among actual stocks (Begg and Waldman 1999, Ünlü et al. 2012, Coad 2014). Studies of morphological variation among populations still play an important role in stock identification because stable differences in shape among fish groups can reveal different growth, mortality, or reproduction rates relevant to the definition of the stocks (Swain and Foote 1999, Cadrin 2000).

Geographically, the Tunisian shore is a border region between the basins of the eastern and western Mediterranean that contain many lagoons, including the Bizerte, Kelibia, Monastir, and Zarzis. Their geographical location means they are important ecological niches that provide more potential biodiversity to the Tunisian coast (Kaoučche et al. 2017). Previous ecological studies at stations in the Bizerte, Kelibia, Monastir, and Zarzis lagoons showed that environmental characteristics such as temperature, salinity, and currents differed in these locations (Béjaoui et al. 2008, 2010, 2019, Martins et al. 2015, Jamila et al. 2016, Kaoučche et al. 2017, Zaafrane et al. 2019). Anthropogenic pressures including urbanization, industrial activities, naval and commercial shipping harbors, and organic chemical and heavy metal pollution also differed among the sites (Barhoumi 2014). These environmental changes among the four stations were expected to induce variation in fish phenology to permit adaptations to environmental changes by adjusting fish physiology and behavior to the effects of environmental variation, which would lead to changes in morphology, reproduction, and survival (Stearns 1983, Meyer 1987). Variation in morphological characters resulting from changes in environmental factors could be useful for stock identification, especially when time scales are inadequate for important genetic differentiation in populations, which can occur in partially isolated stocks.

The bogue, Boops boops (L.), is one of the most widespread commercial seabream species in the Mediterranean, including in Tunisian waters, the Eastern Atlantic, and the Black Sea (Khemiri et al. 2005, Amira et al. 2019). It is a gregarious, demersal, semi-pelagic species that is found at a depth of 350 $\mathrm{m}$ above a variety of substrata, including sand, mud, rocks, and seaweeds (Ceyhan et al. 2018, Şimşek et al. 2018). However, it is more common at depths of less than $150 \mathrm{~m}$ and is sometimes found in coastal waters. This species moves in aggregations and 
mainly ascends to the surface at night (Ider et al. 2017). B. boops grows rapidly in length during the first year of life, where it reaches $53.49 \%$ of its final length, and it can live up to seven years (Pollard et al. 2014). In Egypt, Azab et al. (2019) reported that its total length ranged from 9.3 to $23 \mathrm{~cm}$ and its total weight ranged from 7.4 to $133.1 \mathrm{~g}$, while the length-weight relationship revealed a tendency toward isometric growth. These researchers also determined that its longevity is four years, and the lengths at first capture and first maturity were 12.5 and 13.2 $\mathrm{cm}$, respectively, while the total mortality rate was $2.26 \mathrm{y}^{-1}$. Conversely, Kara and Bayhan (2008) reported that the length-weight relationship showed allometric growth and the length-length relationships were highly correlated $(P<0.001)$ in Izmir Bay (Aegean Sea of Turkey). Similarly, Soykan et al. (2015) described length-weight relations as positively allometric with lengths at first maturity of $12.96 \mathrm{~cm}$ for females and $9.35 \mathrm{~cm}$ for males from the waters of the Turkish coast of the Aegean Sea. Additionally, Özvarol (2016) reported no statistically significant differences between the length groups of escapees and catches in the Gulf of Antalya (northeastern Mediterranean Sea). Moreover, Monteiro et al. (2006) reported that sexual maturity was reached between ages one and three at a length of about $15.22 \mathrm{~cm}$ for both sexes in the Algarve (southern Portugal). Along the Benghazi Mediterranean coast, $B$. boops feeds on a wide variety of prey species, including Crustacea (49.0\%), Porifera (22.7\%), Coelenterata $(10.2 \%)$, seagrasses $(9.2 \%)$, Mollusca (8.1\%), and Protozoa (0.9\%) (El-Maremie and El-Mor 2015), while along the Algerian coast it is omnivorous and feeds on benthic (Crustacea, Mollusca, Annelida, Sipuncula, Plantae) and pelagic (Siphonophorae, Copepoda, eggs) prey (Derbal and Kara 2008).

In Tunisian waters, however, Anato and Ktari (1986) studied the age and growth of B. boops with otolith and scale readings and found that the first sexual maturity age was between the thirteenth and fifteenth months after birth and female linear growth and weight increased slightly over males during the first four years of life. Khemiri et al. (2005) also determined the age and growth in fish from four areas along the Tunisian coast by studying growth in cross-sections of otoliths; they reported that hyaline zones were deposited annually from November to April and that the increases in length and age fit Von Bertalanffy equations. Additionally, Cherif et al. (2008) analyzed the length-weight relationship of individuals in the Gulf of Tunis and found a high degree of positive correlation between total length and total weight. Moreover, the infection of the B. boops gallbladder with Ceratomyxa ghannouchensis and $C$. pallida parasites in the Gulf of Gabes was confirmed by Thabet et al. (2019). Furthermore, Ben Labidi et al. $(2020 \mathrm{a}, \mathrm{b})$ found that there was asymmetry in otolith shape within and among stocks of $B$. boops from the stations studied.

Thus, there is currently no knowledge of the $B$. boops stock structure in Tunisia. Thus, the aim of this study was to investigate the morphological population structure of $B$. boops in four different stations along the Tunisia coast based on an examination of 14 morphometric and seven meristic characters to determine whether they constitute one demographic unit or independent management groups. There is also a brief discussion of their relationships and the impact of environmental factors on their morphological structure.

\section{Material and Methods}

\section{Study area and sampling}

A total of 518 samples of B. boops were collected between May 2018 and July 2019 from four sampling stations located in the Bizerte, Kelibia, Monastir, and Zarzis lagoons, which cover most of the geographical distribution of this species along the Tunisian coast (Fig. 1). The sampling size, total weight, and geographical coordinates of these stations are given in Table 1. Fish samples were caught alive with gillnets from coastal boats ranging from 5 to $13 \mathrm{~m}$ in length. Immediately after they were caught, the total weight of each fish specimen was recorded and the values were rounded to the nearest $0.1 \mathrm{~g}$ (Table 1 ). 


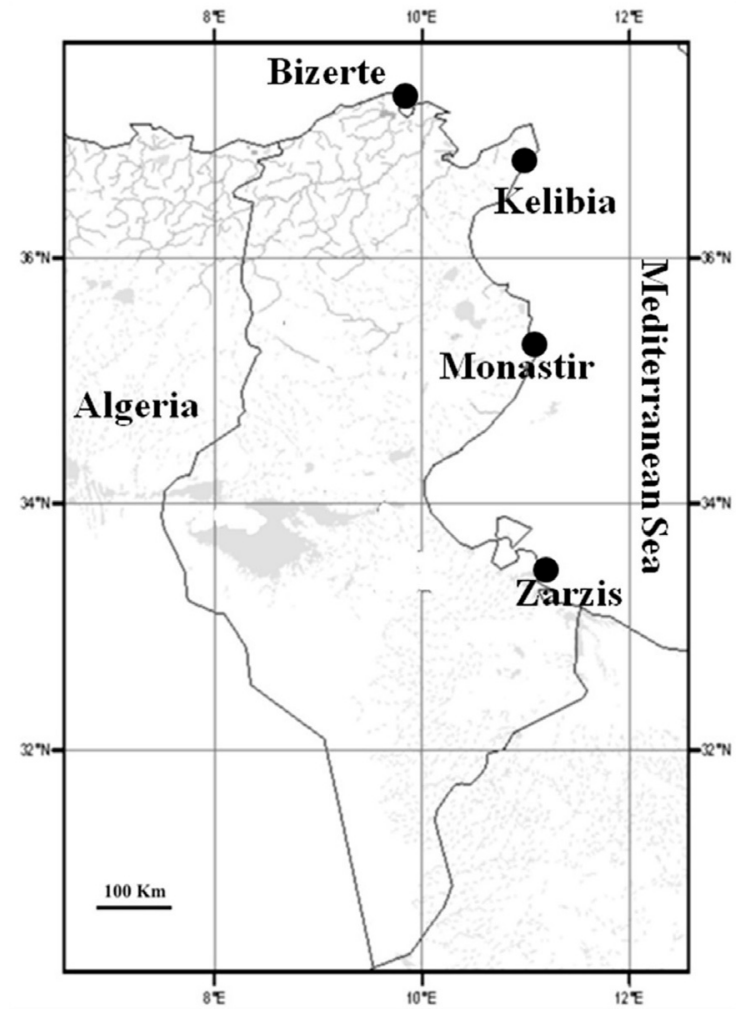

Figure 1. Map showing collection sites of B. boops at the Bizerte, Kelibia, Monastir, and Zarzis stations, Tunisia.

\section{Morphometric and meristic characters}

A total of 14 morphometric and seven meristic characters were used for the present study. These characters and their corresponding abbreviations are shown in Fig. 2. The morphometric characters were measured from the left side of the fish using digital calipers and values were rounded to the nearest 0.01 $\mathrm{mm}$ (Table 2). Meristic characters were counted for all the samples from the left side of the fish following the method of Hubbs and Lagler (1958). Details and abbreviations of these characters are given in Table 3 . The gill rakers of the first gill arch were counted under a dissecting microscope after the removal of the anterior gill arch. Sex was determined macroscopically, and the effect of sex on truss measurements was tested using univariate statistics (ANOVA). However, to eliminate the biased effect of large measurements related to the large size of fish on the statistical analysis, the values of the
Table 1

Sampling sites with coordinates, sample size, and total weight (range and mean \pm standard deviation (SD) values) of $B$. boops samples collected at the four stations in Tunisia

\begin{tabular}{|c|c|c|c|c|}
\hline \multirow{2}{*}{$\begin{array}{l}\text { Sampling } \\
\text { site }\end{array}$} & \multirow{2}{*}{$\begin{array}{l}\text { Sample } \\
\text { size }\end{array}$} & \multicolumn{2}{|c|}{ Total weight (in g) } & \multirow{2}{*}{$\begin{array}{l}\text { Geographic } \\
\text { coordinates }\end{array}$} \\
\hline & & Range & Mean \pm SD & \\
\hline Bizerte & 118 & $37-60$ & $46.16 \pm 7.63$ & $\begin{array}{c}\left(37^{\circ} 16^{\prime} 27^{\prime \prime} \mathrm{N}\right. \\
\left.9^{\circ} 52^{\prime} 26^{\prime \prime} \mathrm{E}\right)\end{array}$ \\
\hline Kelibia & 147 & $39-70$ & $49.93 \pm 9.12$ & $\begin{array}{l}\left(36^{\circ} 50^{\prime} 51^{\prime \prime} \mathrm{N}\right. \\
\left.11^{\circ} 05^{\prime} 37^{\prime \prime} \mathrm{E}\right)\end{array}$ \\
\hline Monastir & 103 & $42-72$ & $54.04 \pm 9.42$ & $\begin{array}{l}\left(35^{\circ} 46^{\prime} 40^{\prime \prime} \mathrm{N}\right. \\
\left.10^{\circ} 49^{\prime} 34^{\prime \prime} \mathrm{E}\right)\end{array}$ \\
\hline Zarzis & 150 & $45-78$ & $58.43 \pm 9.57$ & $\begin{array}{l}\left(33^{\circ} 30^{\prime} 14^{\prime \prime} \mathrm{N}\right. \\
\left.11^{\circ} 06^{\prime} 43^{\prime \prime} \mathrm{E}\right)\end{array}$ \\
\hline All & 518 & $37-78$ & $52.14 \pm 9.11$ & - \\
\hline
\end{tabular}

morphometric characters measured were first transformed into size-independent shape variables. Size-dependent variation for morphometric and meristic characters was removed using the Reist (1985) equation, where the base-10 logarithm was used for all variables. This equation is proven to be effective in removing such size-dependent variation (Hauser et al. 1995, Turan 2000).

\section{Statistical analyses}

All statistical analyses were performed using Past v.1.81 (Hammer et al. 2001) and Statistica v.12.5 (StatSoft, Inc.). Univariate analysis of variance (ANOVA) was performed on standardized data for both types of characters to compare variation among samples for size-adjusted truss measurements. The number of significantly different measurements among the populations of the four stations was an additional indication of the degree of population separation. A posteriori Scheffé's (1959) post-hoc multiple comparison tests were also performed to determine the number of significant characters between pairs of samples. A non-parametric multiple analysis of variance (MANOVA) was conducted to test the significance of each character difference among populations using Shapiro-Wilks' $\lambda$ test 


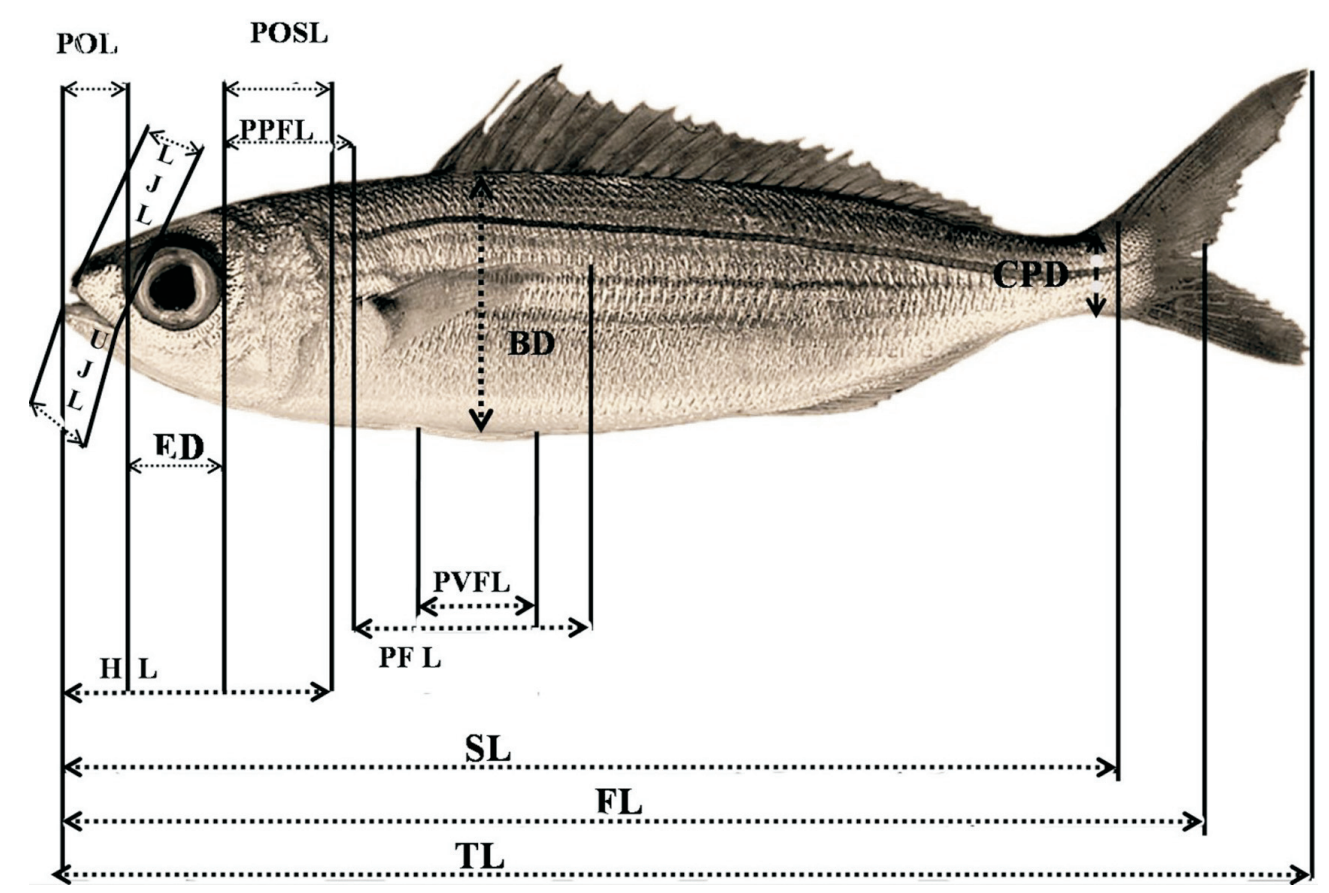

Figure 2. Morphometric measurements of the bogue, B. boops. ED - Eye diameter; BD - Body depth; CPD - Caudal peduncle depth; HL - Head length; TL - Total length; SL - Standard length; FL - Fork length; POL - Preorbital length; POSL - Postorbital length; UJL - Upper jaw length; LJL - Lower jaw length; PFL - Pectoral fin length; PVFL - Pelvic fin length; PPFL - Prepectoral fin length.

Table 2

Range and mean \pm standard deviation (SD) values of the 14 morphometric characters of B. boops samples collected at the four stations in Tunisia

\begin{tabular}{|c|c|c|c|c|c|c|c|c|}
\hline \multirow[b]{3}{*}{ Character } & \multicolumn{8}{|c|}{ Sampling site } \\
\hline & \multicolumn{2}{|l|}{ Bizerte } & \multicolumn{2}{|l|}{ Kelibia } & \multicolumn{2}{|l|}{ Monastir } & \multicolumn{2}{|l|}{ Zarzis } \\
\hline & Range & Mean \pm SD & Range & Mean \pm SD & Range & Mean \pm SD & Range & Mean \pm SD \\
\hline TL & $152-188$ & $168.30 \pm 8.50$ & $126-193$ & $162.06 \pm 14.44$ & $152-198$ & $172.35 \pm 9.98$ & $148-206$ & $172.79 \pm 10.46$ \\
\hline SL & $129-155$ & $140.30 \pm 6.20$ & $114-172$ & $139.94 \pm 10.86$ & $128-166$ & $143.93 \pm 8.88$ & $125-170$ & $144.11 \pm 8.86$ \\
\hline $\mathrm{FL}$ & $139-174$ & $156.89 \pm 8.41$ & $125-188$ & $154.93 \pm 11.48$ & $140-178$ & $158.84 \pm 8.79$ & $140-188$ & $159.27 \pm 9.37$ \\
\hline $\mathrm{BD}$ & $21.4-39$ & $27.93 \pm 2.10$ & $22.04-24.97$ & $23.52 \pm 0.85$ & $22.44-44.71$ & $31.85 \pm 6.72$ & $22.66-44.86$ & $33.69 \pm 6.51$ \\
\hline CPD & $8.35-12.2$ & $10.48 \pm 0.84$ & $8.03-12.43$ & $10.24 \pm 1.28$ & $8.62-11.92$ & $10.44 \pm 0.90$ & $8.95-11.94$ & $10.45 \pm 0.87$ \\
\hline $\mathrm{HL}$ & $29.9-42.50$ & $33.53 \pm 1.82$ & $29.61-31.82$ & $30.72 \pm 0.64$ & $29.91-34.53$ & $31.48 \pm 0.10$ & $30.08-33.05$ & $31.56 \pm 0.87$ \\
\hline ED & $10.01-14.02$ & $12.06 \pm 0.83$ & $11.34-14.87$ & $13.11 \pm 1.02$ & $11.20-15.34$ & $13.59 \pm 0.97$ & $12.08-15.36$ & $13.72 \pm 0.96$ \\
\hline POL & $7.22-11.47$ & $9.45 \pm 1.15$ & 8.30 - 37.99 & $23.24 \pm 8.60$ & $7.25-12.52$ & $9.91 \pm 1.25$ & $14.56-19.20$ & $16.96 \pm 1.31$ \\
\hline POSL & $11.45-16.51$ & $13.86 \pm 1.25$ & $11.26-13.17$ & $12.22 \pm 0.55$ & $11.52-14.01$ & $12.60 \pm 0.58$ & $11.66-13.60$ & $12.63 \pm 0.56$ \\
\hline UJL & $6.75-13.10$ & $9.19 \pm 1.68$ & $6.92-11.19$ & $9.07 \pm 1.23$ & $6.75-12.56$ & $9.99 \pm 1.40$ & $7.82-12.59$ & $10.21 \pm 1.39$ \\
\hline LJL & $7.89-14.60$ & $10.58 \pm 1.93$ & $7.08-11.48$ & $9.29 \pm 1.28$ & $7.68-13.59$ & $10.23 \pm 1.39$ & $8.01-12.77$ & $13.72 \pm 1.39$ \\
\hline PFL & $24.34-31.20$ & $27.61 \pm 1.59$ & $24.63-26.10$ & $25.37 \pm 0.43$ & $24.83-28.45$ & $25.18 \pm 0.45$ & $24.94-25.17$ & $25.06 \pm 0.07$ \\
\hline PVFL & $16.85-22.70$ & $19.56 \pm 1.48$ & $17.66-41.17$ & $29.50 \pm 6.81$ & $18.10-38.29$ & $24.59 \pm 3.82$ & $22.62-24.58$ & $23.66 \pm 0.52$ \\
\hline PPFL & $14.15-36.18$ & $17.89 \pm 3.73$ & $14.25-35.10$ & $24.42 \pm 5.90$ & $15.57-35.99$ & $20.44 \pm 3.69$ & $18.24-21.54$ & $19.82 \pm 1.15$ \\
\hline
\end{tabular}


Table 3

Range, mode, and mean \pm standard deviation (SD) counts of the 7 meristic characters of B. boops samples collected at the four stations in Tunisia

\begin{tabular}{|c|c|c|c|c|c|}
\hline Character & Sampling site & $\begin{array}{l}\text { Sample } \\
\text { size }\end{array}$ & Range & Mode & Mean \pm SD \\
\hline \multirow[t]{4}{*}{ Number of anal fin rays (NAFR) } & Bizerte & 118 & $11-28$ & 18 & $18.07 \pm 4.93$ \\
\hline & Kelibia & 147 & $11-28$ & 17 & $17.66 \pm 4.69$ \\
\hline & Monastir & 103 & $11-30$ & 21 & $20.38 \pm 4.17$ \\
\hline & Zarzis & 150 & $11-28$ & 22 & $20.67 \pm 3.52$ \\
\hline \multirow[t]{4}{*}{ Number of vertebrae (NV) } & Bizerte & 118 & $22-23$ & 22 & $22.00 \pm 0.09$ \\
\hline & Kelibia & 147 & $22-23$ & 22 & $22.02 \pm 0.14$ \\
\hline & Monastir & 103 & $22-22$ & 22 & $22.00 \pm 0.00$ \\
\hline & Zarzis & 150 & $22-22$ & 22 & $22.00 \pm 0.00$ \\
\hline \multirow[t]{4}{*}{ Number of left pelvic fin rays (NPFRleft) } & Bizerte & 118 & $14-24$ & 17 & $17.82 \pm 2.73$ \\
\hline & Kelibia & 147 & $11-24$ & 18 & $17.15 \pm 2.54$ \\
\hline & Monastir & 103 & $13-24$ & 18 & $18.48 \pm 2.86$ \\
\hline & Zarzis & 150 & $14-25$ & 17 & $17.96 \pm 2.99$ \\
\hline \multirow[t]{4}{*}{ Number of right pelvic fin rays (NPFRright) } & Bizerte & 118 & $12-24$ & 18 & $17.74 \pm 2.63$ \\
\hline & Kelibia & 147 & $12-24$ & 19 & $17.61 \pm 2.25$ \\
\hline & Monastir & 103 & $13-25$ & 17 & $18.56 \pm 2.84$ \\
\hline & Zarzis & 150 & $12-25$ & 18 & $18.10 \pm 2.53$ \\
\hline \multirow[t]{4}{*}{ Number of gill rakers on left first gill arch (NGRleft) } & Bizerte & 118 & $20-33$ & 24 & $25.04 \pm 3.567$ \\
\hline & Kelibia & 147 & $24-31$ & 24 & $24.59 \pm 3.70$ \\
\hline & Monastir & 103 & $13-32$ & 31 & $26.21 \pm 4.08$ \\
\hline & Zarzis & 150 & $20-33$ & 24 & $25.11 \pm 4.01$ \\
\hline \multirow[t]{4}{*}{ Number of gill rakers on right first gill arch (NGRright) } & Bizerte & 118 & $20-35$ & 23 & $24.90 \pm 3.70$ \\
\hline & Kelibia & 147 & $15-33$ & 24 & $24.78 \pm 3.50$ \\
\hline & Monastir & 103 & $12-33$ & 22 & $25.72 \pm 4.11$ \\
\hline & Zarzis & 150 & $19-34$ & 22 & $25.31 \pm 3.90$ \\
\hline \multirow[t]{4}{*}{ Number of pectoral fin rays (NPER) } & Bizerte & 118 & $12-22$ & 15 & $17.29 \pm 2.73$ \\
\hline & Kelibia & 147 & $11-25$ & 16 & $17.11 \pm 2.87$ \\
\hline & Monastir & 103 & $14-25$ & 18 & $18.15 \pm 2.56$ \\
\hline & Zarzis & 150 & $12-25$ & 19 & $18.68 \pm 2.69$ \\
\hline
\end{tabular}

(Klecka 1980). The transformed variables were submitted to canonical variant analysis (CVA). CVA maximizes the amount of multivariate variation among populations relative to within-population variation and identifies those variables that serve best to discriminate between populations by location and percentages of correct classifications (Bookstein 1982). The dissimilarity matrix of characters among populations was calculated using Euclidean distance (Clifford and Stephenson 1975). Hierarchical cluster analysis was performed based on the Euclidean distance matrix of dissimilarity using unweighted pair-group matrix analysis with the arithmetic average (UPGMA) method (Sneath and Sokal 1973) to assess relationships among populations. 


\section{Results}

\section{Morphometric characters}

Univariate analysis of variance (ANOVA) revealed that $13(92.9 \%)$ of the 14 characters, except CPD (caudal peduncle depth), were significantly different among the populations of the four stations. Likewise, both Scheffe's post-hoc test (Table 4) and MANOVA showed statistically significant differences among the four populations (Wilks' $\lambda=0.013, F=118.7, \mathrm{P}=$ 0.00 ). In addition, CVA showed that the scatter plot for CV1 and CV2 generated a clear separation of all samples into four groups, or morphotypes, corresponding to the four populations (Fig. 3a). CV1 accounted for the largest amount of among-group variability $(58.32 \%)$ and was associated with POL (main loading $=0.7$ ), while CV2 accounted for $34.81 \%$ and was also associated with POL (main loading $=0.55$ ). The overall percentage of correct classification of individuals to their populations of origin was $95.36 \%$, while their percentages of correct classification in the populations of Bizerte, Kelibia, Monastir, and Zarzis were 91.52\%, 95.23\%, 97.08, and $97.33 \%$, respectively. The percentages of morphological differences among the four populations indicated highly significant differences (Wilks' $\lambda=$ 0.004; $\mathrm{P}<0.0001)$. The dissimilarity matrix computed using Euclidean distance for the morphometric parameters is shown in Table 5. The

\section{Table 4}

Summary of the ANOVA results of the 14 morphometric and 7 meristic characters of $B$. boops samples collected at the four stations in Tunisia. Significance levels; * $-P<0.05 ;{ }^{*}-P<0.01{ }^{*}{ }^{*} *-P<0.001$

\begin{tabular}{|c|c|c|c|c|c|c|c|c|}
\hline \multirow[b]{2}{*}{$\begin{array}{l}\text { Morphometric } \\
\text { characters }\end{array}$} & \multirow[b]{2}{*}{$\mathrm{F}$} & \multirow[b]{2}{*}{$\mathrm{P}$} & \multicolumn{6}{|c|}{ Sampling site } \\
\hline & & & $\begin{array}{l}\text { Bizerte - } \\
\text { Kelibia }\end{array}$ & $\begin{array}{l}\text { Bizerte - } \\
\text { Monastir }\end{array}$ & $\begin{array}{l}\text { Bizerte - } \\
\text { Zarzis }\end{array}$ & $\begin{array}{l}\text { Kelibia - } \\
\text { Monastir }\end{array}$ & $\begin{array}{l}\text { Kelibia - } \\
\text { Zarzis }\end{array}$ & $\begin{array}{l}\text { Monastir - } \\
\text { Zarzis }\end{array}$ \\
\hline TL & 27.250 & $<0.001$ & $* * *$ & & * & $* * *$ & $* * *$ & \\
\hline SL & 8.338 & $<0.001$ & & * & $* *$ & $* *$ & $* *$ & \\
\hline FL & 5.909 & $<0.001$ & & & & $*$ & $* *$ & \\
\hline BD & 123.053 & $<0.001$ & $* * *$ & $* * *$ & $* * *$ & $* * *$ & $* * *$ & * \\
\hline CPD & 1.610 & 0.185 & & & & & & \\
\hline $\mathrm{HL}$ & 144.456 & $<0.001$ & $* * *$ & $* *$ & $* * *$ & $* * *$ & $* * *$ & \\
\hline ED & 77.107 & $<0.001$ & $* * *$ & $* * *$ & $* * *$ & $* *$ & $* * *$ & \\
\hline POL & 250.876 & $<0.001$ & $* * *$ & & $* * *$ & $* * *$ & $* * *$ & $* * *$ \\
\hline POSL & 106.272 & $<0.001$ & $* * *$ & $* * *$ & $* * *$ & $* *$ & $* * *$ & \\
\hline UJL & 21.675 & $<0.001$ & & $* * *$ & $* * *$ & $* * *$ & $* * *$ & \\
\hline LJL & 20.299 & $<0.001$ & $* * *$ & & & $* * *$ & $* * *$ & \\
\hline PFL & 266.656 & $<0.001$ & $* * *$ & $* *$ & $* * *$ & & * & \\
\hline PVFL & 133.309 & $<0.001$ & $* * *$ & $* * *$ & $* * *$ & $* * *$ & $* * *$ & \\
\hline PPFL & 63.944 & $<0.001$ & $* * *$ & $* * *$ & $* *$ & $* * *$ & $* * *$ & \\
\hline NAFR & 17.1018 & $<0.001$ & & $* *$ & $* * *$ & $* * *$ & $* * *$ & \\
\hline NV & 1.691 & 0.167 & & & & & & \\
\hline NPFRleft & 4.870 & $<0.01$ & & & & $* *$ & & \\
\hline NPFRright & 3.2841 & 0.05 & & & & & & \\
\hline NPER & 10.300 & $<0.001$ & & & $* * *$ & $*$ & $* * *$ & \\
\hline NGRleft & 3.668 & $<0.05$ & & & & $*$ & & \\
\hline NGRright & 1.500 & 0.213 & & & & & & \\
\hline
\end{tabular}



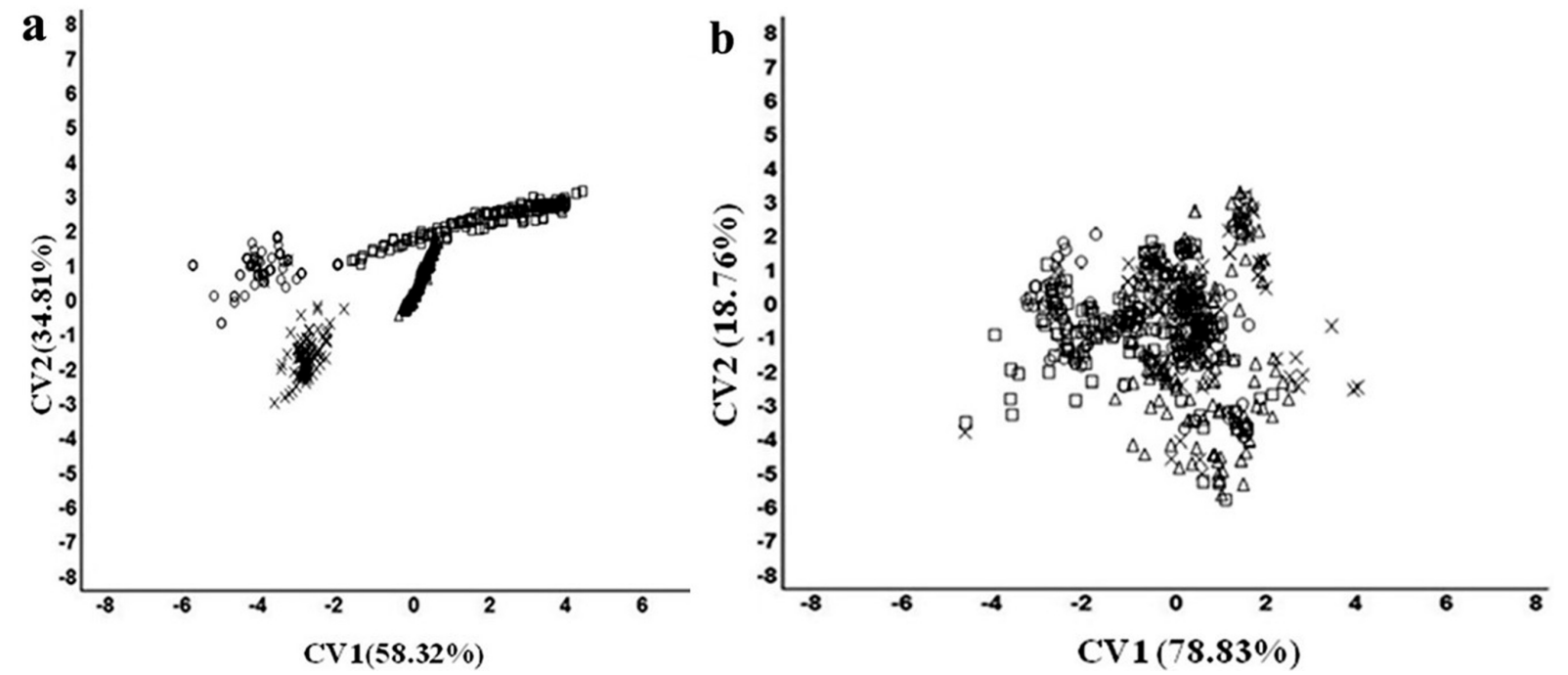

Figure 3. Scatter plot of the CV1 and CV2 axes of the CVA of (a) morphometric characters; (b) meristic characters of B. boops samples collected at four stations along the Tunisian coast. $\square, \triangle, \mathrm{O}$, and $\mathrm{X}$ refer to individuals from the Kelibia, Zarzis, Bizerte, and Monastir stations, respectively.

Table 5

Dissimilarity matrix of morphometric characters (above the diagonal) and meristic characters (below the diagonal) characters using Euclidean distance

\begin{tabular}{lllll}
\hline \hline & Bizerte & Kelibia & Monastir & Zarzis \\
\hline \hline Bizerte & - & 19.36 & 22.76 & 31.54 \\
Kelibia & 9.7 & - & 16.65 & 24.54 \\
Monastir & 11.9 & 8.2 & - & 20.17 \\
Zarzis & 19.2 & 13.7 & 9.84 & - \\
\hline \hline
\end{tabular}

a

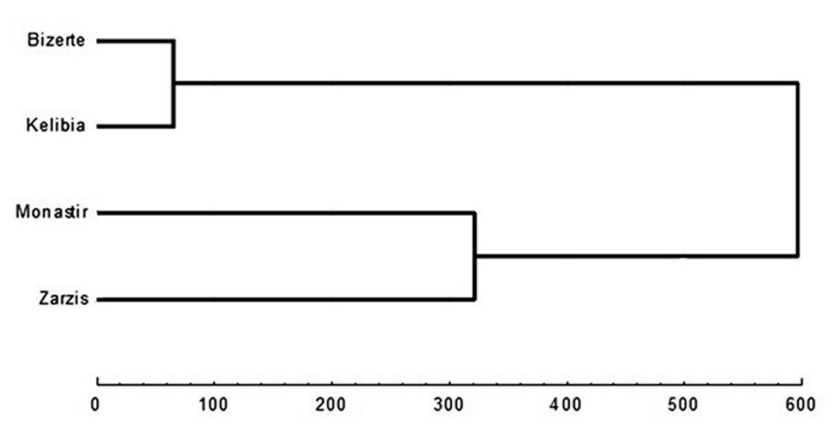

b

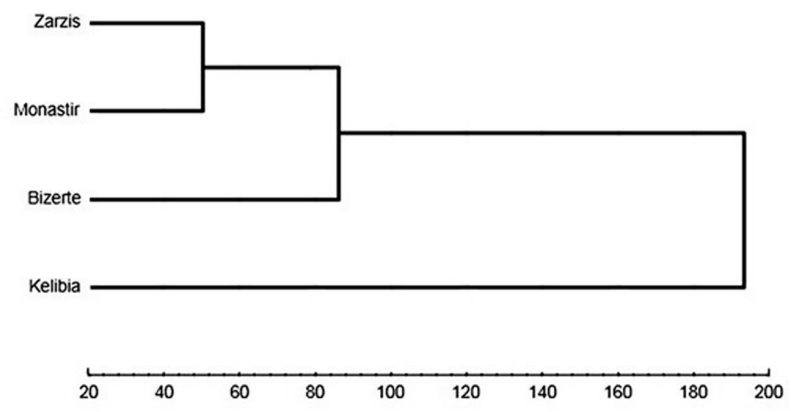

Figure 4. Cluster analysis dendrogram generated based on the Euclidean distance matrix of dissimilarity of the (a) morphometric characters; (b) meristic characters using the UPGMA method showing the relationship among populations of B. boops collected at the Bizerte, Kelibia, Monastir, and Zarzis stations, Tunisia.

dendrogram generated by cluster analysis based on Euclidean distances of dissimilarity among the four populations using the UPGMA method showed two main groups, or clusters. The first comprised the populations of Bizerte and Kelibia, while the second included those of Monastir and Zarzis (Fig. 4a). 


\section{Meristic characters}

Univariate analysis of variance (ANOVA), Scheffé's post-hoc test, and MANOVA revealed statistically significant differences among the four populations in only four (57.1\%) of the seven meristic characters. In detail, ANOVA showed significant differential differences between populations, especially in NAFR, NPFRleft, NPER, and NGRleft. Scheffé's post-hoc test, as well as ANOVA and Wilks' $\lambda$ test, showed significant differences $(\mathrm{P}<0.001)$ in both NAFR and NPER between the populations of Bizerte and Monastir, Bizerte and Zarzis, Kelibia and Monastir, and Kelibia and Zarzis. However, both NPFRleft and NGRleft displayed significant differences $(\mathrm{P}<0.001$ and $\mathrm{P}<0.05$, respectively) only between the Kelibia and Monastir populations (Table 4). In addition, the scatter plot for CV1 and CV2 showed clear differentiation only between the populations of Monastir and Zarzis, while there was overlapping differentiation between those of Bizerte and Kelibia (Fig. 3b). CV1 accounted for $78.83 \%$ of between-group variability and was correlated with NAFR (main loading = 0.71), while CV2 accounted for $18.76 \%$ and was correlated with NGR left (main loading $=0.72$ ). The overall percentage of correct assignment or classification of individuals to their original populations was $51.75 \%$, while their percentages of correct classification to their populations were $57.14 \%$ in Monastir, $56.66 \%$ in Zarzis, $49.42 \%$ in Bizerte, and $46.78 \%$ in Kelibia. Hierarchical cluster analysis based on the Euclidean distances of dissimilarity among the four populations (Table 5) resulted in three primary clusters (Fig. 4b). The first cluster contained the Zarzis and Monastir populations. The second comprised the Bizerte population and joined the first, while the third included the Kelibia population and linked it to the Bizerte population.

\section{Discussion}

The current TL measurements of 518 B. boops samples revealed that TL ranged from 126 to $206 \mathrm{~mm}$. Khemiri et al. (2005) analyzed 3,000 samples of $B$. boops from Tunisian waters and confirmed that the TL ranged from 61 to $320 \mathrm{~mm}$, while Cherif et al. (2008) reported a range of 120 to $260 \mathrm{~mm}$ from the examination of 243 samples from the Gulf of Tunis. However, Ceyhan et al. (2018) recorded a TL of 420 $\mathrm{mm}$ and a weight of $986 \mathrm{~g}$ from different geographical areas in Gull Bay, Turkey, compared to a TL range of $9.3-23 \mathrm{~cm}$ and a total weight range of 7.4-133.1 g in Alexandria, Egypt (Azab et al. 2019). Therefore, we suggest that the differences observed in the range of TL could be related to different growth rates under the influence of environmental conditions and food resources specific to each sampling station. Additionally, differences in TL could also reflect the degree of exploitation to which the different populations were exposed and non-exhaustive sampling (Khaldi and Chakroun-Marzouk 2016).

Statistical analyses of morphometric characters showed significant variation among the four populations in only 13 characters (Wilks's $\lambda=0.004$; $\mathrm{P}<0.0001)$. Additionally, CVA and cluster analysis showed a distinct relationship among the four populations. Similar morphological differentiation results were reported recently for the sparid fish Lithognathus mormyrus (L.) (Hammami et al. 2011, 2013), Diplodus vulgaris (Geoffroy Saint-Hilaire) (Kaoučche et al. 2013), Diplodus puntazzo (Walbaum) (Hammami et al. 2016), and Diplodus sargus (L.) (Kaoučche et al. 2017) inhabiting different habitats in Tunisia, as well as for B. boops collected at seven sampling sites along the Algerian coast (Abla et al. 2018). Prabakaran et al. (2014) found that 10 of 16 morphometric and meristic characters were highly correlated with total length in Nemipterus japonicus (Bloch) from the Chennai Coast. Indeed, the morphological differences found among Tunisian B. boops populations could reflect differences in the physico-chemical characteristics of water, such as temperature, hydrodynamics, turbidity, salinity, and substrata (Moussa et al. 2005, Hammami et al. 2011). Undoubtedly, environmental influences on fish morphometric characters are well documented. For example, Stearns (1983), Meyer (1987), and Guill et al. (2003) stated that changes in fish body shape allow them to adapt to any changes 
in the habitats they live in by modifying their physiology and behavior. Other researchers assumed that morphometric characters changed with water temperature, which could affect fish metabolism through changes in dissolved oxygen (Georgakopoulou et al. 2007, Sfakianakis et al. 2011, Jawad and Al-Janabi 2016). Wimberger (1992) also reported that the viscosity and density of water increased with decreases in water temperature, and, thus, changes in the shape of the body would be advantageous to decrease drag. Additionally, Matthews (1988) found that low light intensity from reduced water turbidity could influence fish eye development. Similarly, salinity clearly affected morphological differentiation in fish species (Akbarzadeh et al. 2009, Siddik et al. 2016). Previous environmental studies at the present four stations showed that at the Bizerte station the water temperature range was $15-16^{\circ} \mathrm{C}$, salinity was 37.5\% (Kaoučche et al. 2017) and the waters were polluted with persistent organic pollutants (POPs), metals, and nutrients that were received through uncontrolled discharges of municipal and industrial wastes, in addition to raw sewage that was back-washed from the sea into the lagoon during high tides and the concentrations of which were generally high at the water surface during the rainy season as was characterized by the abundance and quality of food (Zrafi-Nouira et al. 2008, Barhoumi 2014, Martins et al. 2015, Jamila et al. 2016). However, at Kelibia station, the water temperature ranged from 12.6 to $22.8^{\circ} \mathrm{C}$, the salinity was from $35.4 \%$ in winter to $37.5 \%$ in summer, and it was mostly polluted with biological and biochemical pollutants that varied throughout the seasons of the year (Boulajfene et al. 2019). Water temperature ranged from 19.6 to $25.8^{\circ} \mathrm{C}$ at Monastir (Zaafrane et al. 2019) and from 15.6 to $28.3^{\circ} \mathrm{C}$ at Zarzis (Béjaoui et al. 2019), while the salinity varied from 37\%o in Monastir to 39.5\%o in Zarzis (Kaoučche et al. 2017, Béjaoui et al. 2019), and significant differences in substrates and habitats were determined previously by Mejri et al. (2018). Therefore, we can conclude that the morphological differentiation identified in the present study among the four populations of $B$. boops can be attributed to local changes in physico-chemical water properties at these four stations. Additionally, the availability of food in fish habitats can potentially determine morphometric distinctions among fish (Turan et al. 2006). According to Derbal and Kara (2008) and El-Maremie and El-Mor (2015), B. boops is an omnivorous fish that is observed feeding on a wide range of prey species, such as Crustacea, Porifera, Coelenterata, seagrasses, Mollusca, Protozoa, Annelida, Sipuncula, Plantae, Siphonophorae, Copepoda, and eggs along the coasts of Algeria and Benghazi. Depending on the environmental characteristics prevalent at each of these stations, the availability and abundance of potential prey could vary among them. Thus, in light of the lack of data on the B. boops diet in Tunisian waters, we can assume that there could be a difference in diet composition that might reflect prey availability with the heterogeneity of target environments along the Tunisian coast, especially at these stations. We can also justify the conclusion that the environmental differences among the four stations can present different intrinsic influences, such as hydrodynamics, turbidity, temperature, salinity, and substrata, and that they offer different ecological niches with different diets that, in turn, lead to morphological adaptations. Therefore, the morphological variation among $B$. boops stock populations at these four stations could be attributed to phenotypic plasticity in response to these environmental parameters. However, some authors have suggested that morphometric divergence in fish species can be attributed either to the impact of habitat differences (Hammami et al. 2011, Kaoučche 2012) or to the interaction of both environmental components and genetic data (Bahri-Sfar and Ben Hassine 2009, Mejri et al. 2012); however, the latter hypothesis cannot be discussed here because of a lack of genetic data on B. boops in Tunisia. Moreover, Via et al. (1995) mentioned that when B. boops colonizes a range of heterogeneous environments, a single phenotype is unlikely to be associated with high fitness throughout the range. Besides, Jřrgensen et al. (2008) declared that this fish must adapt to succeed, notably by becoming able to match phenotypes to local environments. Such adaptations might involve changes in morphology, survival features, or 
reproduction (Stearns 1983). Thus, we can suggest that the four morphometric groups or populations of B. boops documented here have thus far adapted to local environments through phenotypic plasticity alone, which is considered an optimal strategy for survival in heterogeneous environments (Kaoučche et al. 2013).

On the other hand, the statistical analysis of meristic characters showed that only four (57.1\%) of the seven characters were significantly different among the populations at the four stations $(\mathrm{P}<$ $0.001,0.01$ or 0.05$)$. CVA and cluster analysis revealed a reticulate relationship among these populations, as there was clear differentiation between those at the Monastir and Zarzis stations and overlap between those at the Bizerte and Kelibia stations. We cited several studies to explain the main causes of variation in meristic characters among fish species. For example, Templeman and Pitt (1961) reported that meristic characters were affected by temperature since the lower the temperature in early life stages, the greater the number of vertebrae. However, Jawad et al. (2017) stated that these variations might result either from environmental or genetic parameters or both. Additionally, Jawad et al. (2018) indicated that the number of vertebrae and the fin ray count could be determined during early larval development and that their number was influenced by environmental parameters, especially temperature, with lower temperatures in early life stages generating greater numbers of vertebrae. Nevertheless, Turan (2000) proposed there was a direct relationship between the extent of phenotypic divergence and the geographical separation of populations and indicated that geographical separation limited migration among populations. Moreover, it has been reported that meristic characters exhibit plasticity under the influence of environmental factors such as temperature, salinity, $\mathrm{pH}$, and oxygen tension, which alter the expression of genes responsible for meristic characters (Dunham et al. 1979, Balon 1980, Todd et al. 1981). Jawad et al. (2017) definitely claimed that warm water temperatures led to shorter incubation periods and lower counts of both fin rays and vertebrae. In the current investigation, the populations at Kelibia and Bizerte, which had the lowest maximum temperature (range $=16-22.8^{\circ} \mathrm{C}$ ), presented the highest number of vertebrae (range $=22-23$ ), while those at Monastir and Zarzis, with the highest maximum temperature range $\left(22.5-38.5^{\circ} \mathrm{C}\right)$ had the lowest number of vertebrae (number $=22$ ). Thus, we can assume that each population adapted locally to the environmental parameters of its habitat, in particular water temperature (Kaoučche et al. 2017). Additionally, only four characters-NAFR, NPFRleft, NPER, and NGRleft-showed significant variation among the populations of the four stations relative to their geographic latitudes. For NAFR, the mean numbers decreased among the populations from 20.67 in

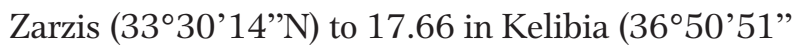
$\mathrm{N})$, while they decreased from 18.48 in Monastir $\left(35^{\circ} 46^{\prime} 40^{\prime \prime} \mathrm{N}\right)$ to 17.15 in Kelibia for NPFRleft. For NPER, they decreased from 18.68 in Zarzis to 17.11 in Kelibia. As for variation in the number of gills rakers, Khalaf-Allah et al. (2016) confirmed that the counts of gill rakers on the first gill arch of B. boops collected in the Mediterranean Sea and Gulf of Suez ranged from 23 to 27 . In the current study, the mean numbers for the NGRleft decreased from 26.21 in Monastir to 24.59 in Kelibia. As described by Kahilainen et al. (2011), fish that feed on small prey items always have numerous gill rakers. Thus, this difference in the number of gills rakers recorded here appeared to be related to the food type and feeding habits of $B$. boops stemming from variation in the availability and abundance of potential prey among the four stations (El-Maremie and El-Mor 2015). In summary, we can assume here that the differences in meristic characters among the populations of the four stations might be attributed either to the fact that the larvae were exposed to different environmental conditions or to the possibility of the existence of geographically separate spawning populations.

In conclusion, the 13 morphometric and four meristic characters analyzed in this study revealed significant morphological discrimination among populations of B. boops collected at four stations located in the lagoons of Bizerte, Kelibia, Monastir, and Zarzis along the Tunisian coast. This phenotypic variability strongly suggests that environmental conditions had an impact 
on it. Therefore, further studies are needed to determine the impacts of environmental factors and diet at these four stations on the morphological population structure of $B$. boops and to garner a better understanding of the contribution of environmental conditions to morphological variation. Additionally, the present results recommend the use of morphometric and meristic characters as reliable keys to provide imperative information for discriminating among B. boops stocks in Tunisian waters. Moreover, these results provide basic information for stock management and will enable efficient management strategies to differentiate among the structures of populations of the B. boops stock to ensure that their fisheries are sustainable and also to develop appropriate conservation plans for Tunisian waters.

Author contributions. M.B.L. collected the fish samples and performed the measurements; M.B.L., H.A. and A.R.B. analyzed and interpreted the data; A.A.B.S., M.T., and J.P.Q. wrote the manuscript. All the authors made substantial intellectual contributions to the work and are prepared to take accountability for it.

Acknowledgments. The authors are very grateful to all people and fishers who helped us to collect the samples for the current investigation. The authors declare that the present research work did not receive any specific grants from funding agents.

\section{ORCID iD}

Adel A. Basyouny Shahin:

(iD) https://orcid.org/0000-0002-9325-0687

\section{References}

Abla, B., Tahar, A., Mezedjri, L. (2018). Comparative biometrics of a teleost fish, Boops boops (Linnaeus, 1758) (Perciformes Sparidae) of the Algerian coast lines. Biodiversity Journal, 9, 121-126.

Akbarzadeh, A., Farahmand, H., Shabani, A.A., Karami, M., Kaboli, M., Abbasi, K., Rafiee, G.R. (2009). Morphological variation of the pikeperch Sander lucioperca (L.) in the southern Caspian Sea, using a truss system. Journal of Applied Ichthyology, 25(5), 576-582.

Amira, S., Alioua, Z., Harchouche, K. (2019). Gonadal development and fecundity of bogue Boops boops (Linnaeus,
1758)(Sparidae) on the central Algerian coast. Turkish Journal of Zoology, 43(1), 12-29.

Anato C.B., Ktari M.H. (1986). Age et croissance de Boops boops (Linne, 1758) Poisson teleosteen Sparidae des cotes Tunisiennes. Bulletin de l'Institut national scientifique et technique d' océanographie et de pęche de Salammbô, 13, 33-54.

Azab, M.A., El-Far, M.A., El-Sayed, M.A. (2019). Age, growth and population structure of bogue, Boops boops, in the Mediterranean waters front Alexandria, Egypt. Egyptian Journal of Aquatic Biology and Fisheries, 23(3), 69-81.

Bahri-Sfar, L., Ben Hassine, O.K. (2009). Clinal variations of discriminative meristic characters of sea bass, Dicentrarchus labrax (Moronidae, Perciformes) populations on Tunisian coasts. Cybium, 33(3), 211-18.

Balon, E.K. (1980). Early ontogeny of the lake charr Salvelinus (Cristivomer) namaycush. In: Charrs: salmonid fishes of the genus Salvelinus, Perspectives in the vertebrate science (Ed.) E.K. Balon, Vol. 1. Dr. W. Junk Pupl. The Hague, Netherlands: 485-562.

Barhoumi B. (2014) Biosurveillance de la pollution de la lagune de Bizerte (Tunisie) par l'analyse comparée des niveaux de contamination et de l'écotoxicité des sédiments et $\mathrm{du}$ biote. Dissertation. Ecologie, Environnement. Université de Bordeaux, Université de Carthage, Tunisie, $313 \mathrm{p}$.

Begg, G.A., Waldman, J.R. (1999). An holistic approach to fish stock identification. Fisheries Research, 43(1-3), 35-44.

Béjaoui, B., Harzallah, A., Moussa, M., Chapelle, A., Solidoro, C. (2008). Analysis of hydrobiological pattern in the Bizerte lagoon (Tunisia). Estuarine, Coastal and Shelf Science, 80(1), 121-129.

Bejaoui, B., Ferjani, D., Zaaboub, N., Chapelle, A., Moussa, M. (2010). Caractérisation hydrobiologique saisonničre de la lagune de Bizerte (Tunisie). Revue des sciences de l'eau, 23(3), 215-232.

Béjaoui, B., Ismail, S.B., Othmani, A., Hamida, O.B.A.B.H., Chevalier, C., Feki-Sahnoun, W., ... Hassen, M.B. (2019). Synthesis review of the Gulf of Gabes (eastern Mediterranean Sea, Tunisia): Morphological, climatic, physical oceanographic, biogeochemical and fisheries features. Estuarine, Coastal and Shelf Science, 219, 395-408.

Ben Labidi, M., Mejri, M., Shahin, A.A.B.S, Quignard, J.P, Trabelsi, M., Ben Faleh, A.R. (2020a). Stock discrimination of the bogue Boops boops (Actinopterygii, Sparidae) form two Tunisian Marine Stations using the otolith shape. Acta Ichthyologica et Piscatoria, 50(4), 413-422.

Ben Labidi, M.B., Mejri, M., Shahin, A.A., Quignard, J.P., Trabelsi, M., Faleh, A.B. (2020b). Otolith fluctuating asymmetry in Boops boops (Actinopterygii, Sparidae) from two marine stations (Bizerte and Kelibia) in Tunisian waters. Journal of the Marine Biological Association of the United Kingdom, 100(7), 1135-1146. 
Bookstein, F.L. (1982). Foundations of morphometrics. Annual Review of Ecology and Systematics, 13(1), 451-470.

Boulajfene, W., Strogyloudi, E., Lasram, M., El Mlayah, A., Vassiliki-Angelique, C., Zouari-Tlig, S. (2019). Biological and biochemical assessment in Phorcus articulatus (Lamarck 1822): contamination and seasonal effect. Environmental Monitoring and Assessment, 191(9), 1-16.

Cadrin, S.X. (2000). Advances in morphometric analysis of fish stock structure. Reviews in Fish Biology and Fisheries, 10, 91-112.

Ceyhan, T., Ertosluk, O., Akyol, O., Özgül, A. (2018). Maximum size of Bogue, Boops boops (Perciformes: Sparidae) for the Mediterranean. Acta Aquatica Turcica 14(4), 399-403.

Cherif, M., Zarrad, R., Gharbi, H., Missaoui, H., Jarboui, O. (2008). Length-weight relationships for 11 fish species from the Gulf of Tunis (SW Mediterranean Sea, Tunisia). Pan-American Journal Aquatic Sciences 3(1): 1-5.

Clifford, H.T., Stephenson, W. (1975). An introduction to numerical classification. Academic Press, New York.

Coad, W.C. (2015). Review of the freshwater catfishes of Iran (Order Siluriformes). Iranian Journal of Ichthyology, 1(4), 218-257.

Dasgupta, M. (1991). Biometry of Mahseer (Tor putitora) collected from Garo Hills, Meghalaya, India. Indian Journal of Fisheries, 38(2), 129-131.

Derbal, F., Kara, M.H. (2008). Composition du régime alimentaire du bogue Boops boops (Sparidae) dans le golfe d'Annaba (Algérie). Cybium, 32(4), 325-333.

Edwin Prabakaran, T., Jeyasingh Thompson, R., Deepak Samuel, V. (2014). Study on the morphometric and meristic characters of the threadfin bream (Nemipterus Japonicus, Bloch 1791) off Chennai coast. Indian Journal of Applied Research, 4(1): 520-524.

Ider, D., Ramdane, Z., Mahe, K., Duffour, J.L., Bacha, M., Amara, R. (2017). Use of otolith-shape analysis for stock discrimination of Boops boops along the Algerian coast (southwestern Mediterranean Sea). African Journal of Marine Science, 39(3), 251-258.

Doherty, D., McCarthy, T.K. (2004). Morphometric and meristic characteristics analyses of two western Irish populations of Arctic Char, Salvelinus alpinus (L.). Biology and Environment, Proceedings of the Royal Irish Academy, 104b(1), 75-85.

Dunham, A.E., Smith, G.R., Taylor, J.N. (1979). Evidence for ecological character displacement in western American catostomid fishes. Evolution, 33(3), 877-896.

El-Maremie, H., El-Mor, M. (2015). Feeding habits of the bogue, Boops boops (Linnaeus, 1758) (Teleostei: Sparidae) in Benghazi coast, eastern Libya. Journal of Life Sciences, 9(5), 189-196.

Fagbuaro, O., Oso, J.A., Olurotimi, M.B., Akinyemi, O. (2015). Morphometric and meristic characteristics of Clarias gariepinus from controlled and uncontrolled population from Southwestern Nigeria. Journal of Agriculture and Ecology Research International, 2(1), 39-45.

Georgakopoulou, E., Sfakianakis, D.G., Kouttouki, S., Divanach, P., Kentouri, M., Koumoundouros, G. (2007). The influence of temperature during early life on phenotypic expression at later ontogenetic stages in sea bass. Journal of Fish Biology, 70(1), 278-291.

Guill, J.M., Heins, D.C., Hood, C.S. (2003). The effect of phylogeny on interspecific body shape variation in darters (Pisces: Percidae). Systematic Biology, 52(4), 488-500.

Hammami, I., Bahri-Sfar, L., Hassine, O.K.B. (2011). Morphological variations of striped seabream, Lithognathus mormyrus, populations along the Tunisian coast. Journal of the Marine Biological Association of the United Kingdom, 91(6), 1261-1271.

Hammami, I., Bahri-Sfar, L., Kaoueche, M., Grenouillet, G., Lek, S., Kara, M., Hassine, O.B. (2013). Morphological characterization of striped seabream (Lithognathus mormyrus, Sparidae) in some Mediterranean lagoons. Cybium, 37(1-2), 127-139.

Hammami, I., Ben Hassine, O.K., Kaoučche, M., Bahri-Sfar, L. (2016). Morphological and genetic characterization of the sharpsnout seabream populations (Diplodus puntazzo, Sparidae) along a boundary area between the two Mediterranean basins. Marine Biology Research, 12(8), 842-853.

Hammer, Ø., Harper, D.A., Ryan, P.D. (2001). PAST: Paleontological statistics software package for education and data analysis. Palaeontologia Electronica, 4(1), 1-9.

Hauser, L., Carvalho, G.R., Pitcher, T.J. (1995). Morphological and genetic differentiation of the African clupeid Limnothrissa miodon 34 years after its introduction to Lake Kivu. Journal of Fish Biology, 47, 127-144.

Hubbs, C.L., Lagler, K.F. (1958). Fishes of the Great Lakes Region. University of Michigan Press, Ann Arbor, MI, USA. 
Ihssen, P.E., Booke, H.E., Casselman, J.M., McGlade, J.M., Payne, N.R., Utter, F.M. (1981). Stock identification: materials and methods. Canadian Journal of Fisheries and Aquatic Sciences, 38(12), 1838-1855.

Jamila, H., Mouldi, B., Moncef, G. (2016). Assessment of the water quality of Bizerte lagoon of Tunisia by use of statistical analyses. Hydrology: Current Research, 7, 237.

Jawad, L.A., Al-Janabi, M.I. (2016). Morphometric characteristics of catfish Silurus triostegus Heckel, 1843 from the Tigris and Ahatt al-Arab rivers, Iraq. Croatian Journal of Fisheries, 74(4), 179-185.

Jawad, L.A., Ligas, A., Al-Janabi, M.I. (2017). Meristic character variability among populations of Silurus triostegus Heckel, 1843 from the Euphrates, Tigris, and Shatt al-Arab Rivers, Iraq. Archives of Polish Fisheries, 25(1), 21-31.

Jawad, L.A., Habbeb, F.S., Al-Mukhtar, M.A. (2018). Morphometric and Meristic Characters of Two Cichlids, Coptodon zillii and Oreochromis aureus Collected from Shatt al-Arab River, Basrah, Iraq. International Journal of Marine Science, 8, 12-24.

Jayasankar, P., Thomas, P.C., Paulton, M.P., Mathew, J. (2004). Morphometric and genetic analyzes of Indian mackerel (Rastrelliger kanagurta) from peninsular India. Asian Fisheries Science, 17, 201-215.

Jřrgensen, H.B., Pertoldi, C., Hansen, M.M., Ruzzante, D.E., Loeschcke, V. (2008). Genetic and environmental correlates of morphological variation in a marine fish: the case of Baltic Sea herring (Clupea harengus). Canadian Journal of Fisheries and Aquatic Sciences, 65(3), 389-400.

Kahilainen, K.K., Siwertsson, A., Gjelland, K.Ø., Knudsen, R., Bøhn, T., Amundsen, P.A. (2011). The role of gill raker number variability in adaptive radiation of coregonid fish. Evolutionary Ecology, 25(3), 573-588.

Kaoučche, M. (2012). Caractérisation parasitologique, morphométrique et génétique des populations tunisiennes de deux espčces de poissons Sparidés: Diplodus sargus et Diplodus vulgaris. Ph.D. thesis, Université de Tunis El Manar, Tunisie.

Kaoučche, M., Bahri-Sfar, L., Hammami, I., Ben Hassine, O.K. (2013). Morphological and genetic variations of Diplodus vulgaris along the Tunisian coasts. Cybium, 37(1-2), 111-20.

Kaoučche, M., Bahri-Sfar, L., Hammami, I., Hassine, O.K.B. (2017). Morphometric variations in white seabream Diplodus sargus (Linneus, 1758) populations along the Tunisian coast. Oceanologia, 59(2), 129-138.

Kara, A., Bayhan, B. (2008). Length-weight and length-length relationships of the bogue Boops boops (Linneaus, 1758) in Izmir Bay (Aegean Sea of Turkey). Belgian Journal of Zoology, 138(2), 154-157.

Khalaf-Allah, M.H., Azab, M.A., Mohamed, A.M. (2016). Morphological differences of gill rakers in some sparid fish species (Family: Sparidae), Egypt. International Journal of Environmental Science and Engineering, 7, 63-72.

Khaldi, A., Chakroun-Marzouk, N. (2016). Biométrie et éthologie alimentaire de deux Sparidae Oblada melanura (Linnaeus, 1758) et Lithognathus mormyrus (Linnaeus, 1758) du golfe de Tunis. Bulletin de l'Institut national scientifique et technique d' océanographie et de pęche de Salammbô, 43, 1-8.

Khemiri, S., Gaamour, A., Zylberberg, L., Meunier, F., Romdahane, M.S. (2005). Age and growth of bogue, Boops boops, in Tunisian waters. Acta Adriatica, 46(2), 159-175.

Klecka, W.R. (1980) Discriminant Analysis. Sage University Press, Series, Sage Publications, Beverly Hills, California, USA.

Liasko, R., Anastasiadou, C., Ntakis, A., Gkenas, C., Leonardos, I.D. (2012). Morphological differentiation among native trout populations in North-Western Greece. Journal of Biological Research, 17, 33-43.

Lindsey, C.C. (1988). Factors controlling meristic variation. In: Fish Physiology, (Ed.) W.S. Hoar, D.J. Randall, Academic Press, San Diego, CA: 197-274.

Martins, M.V.A., Zaaboub, N., Aleya, L., Frontalini, F., Pereira, E., Miranda, P., ... El Bour, M. (2015). Environmental quality assessment of Bizerte Lagoon (Tunisia) using living foraminifera assemblages and a multiproxy approach. PloS one, 10(9), e0137250.

Matthews, W.J. (1988). Morphology, habitat use, and life history. In: Patterns in freshwater fish ecology (Ed.) W.J. Matthews, Chapman and Hall, New York: 455-531.

Mejri, R., Brutto, S.L., Hassine, N., Arculeo, M., Hassine, O.K.B. (2012). Overlapping patterns of morphometric and genetic differentiation in the Mediterranean goby Pomatoschistus tortonesei 
Miller, 1968 (Perciformes, Gobiidae) in Tunisian lagoons. Zoology, 115(4), 239-244.

Mejri, M., Trojette, M., Allaya, H., Ben Faleh, A., Jmil, I., Chalh, A., ... Trabelsi, M. (2018). Use of otolith shape to differentiate two lagoon populations of Pagellus erythrinus (Actinopterygii: Perciformes: Sparidae) in Tunisian waters. Acta Ichthyologica et Piscatoria, 48, 153-161.

Meyer, A. (1987). Phenotypic plasticity and heterochrony in Cichlasoma managuense (Pisces, Cichlidae) and their implications for speciation in cichlid fishes. Evolution, 41(6), 1357-1369.

Monteiro, P., Bentes, L., Coelho, R., Correia, C., Gonçalves, J.M.S., Lino, P.G., ... Erzini, K. (2006). Age and growth, mortality, reproduction and relative yield per recruit of the bogue, Boops boops Linné, 1758 (Sparidae), from the Algarve (south of Portugal) longline fishery. Journal of Applied Ichthyology, 22(5), 345-352.

Moussa, M., Baccar, L., Ben Khemis, R. (2005). La lagune de Ghar El Melh: Diagnostic écologique et perspectives d'aménagement hydraulique. Revue des sciences de l'eau, 18, 13-26.

Murta, A.G. (2000). Morphological variation of horse mackerel (Trachurus trachurus) in the Iberian and North African Atlantic: implications for stock identification. ICES Journal of Marine Science, 57(4), 1240-1248.

O’Reilly, K.M., Horn, M.H. (2004). Phenotypic variation among populations of Atherinops affinis (Atherinopsidae) with insights from a geometric morphometric analysis. Journal of Fish Biology, 64(4), 1117-1135.

Özvarol, Y. (2016). Size selectivity of sorting grid for eight fish species in the Gulf of Antalya, Northeastern Mediterranean Sea. Iranian Journal of Ichthyology, 3(4), 294-303.

Pollard, D., Carpenter, K.E., Russell, B. (2014). Boops boops. The IUCN Red List of Threatened Species 2014: e.T170251A1301787. Downloaded on 29 August 2020.

Reist, J.D. (1985). An empirical evaluation of several univariate methods that adjust for size variation in morphometric data. Canadian Journal of Zoology, 63(6), 1429-1439.

Scheffé, H. (1959). The Analysis of Variance. John Wiley and Sons, New York, NY, USA.

Sfakianakis, D.G., Leris, I., Laggis, A., Kentouri, M. (2011). The effect of rearing temperature on body shape and meristic characters in zebrafish (Danio rerio) juveniles. Environmental Biology of Fishes, 92(2), 197-205.

Siddik, M.A.B., Hanif, M.A., Chaklader, M.R., Nahar, A., Fotedar, R. (2016). A multivariate morphometric investigation to delineate stock structure of gangetic whiting, Sillaginopsis panijus (Teleostei: Sillaginidae). SpringerPlus, 5(1), 1-13.

Silva, A. (2003). Morphometric variation among sardine (Sardina pilchardus) populations from the northeastern Atlantic and the western Mediterranean. ICES Journal of Marine Science, 60(6), 1352-1360.

Simsek, E., Ciloglu, A., Yildirim, A., Pekmezci, G.Z. (2018). Identification and molecular characterization of Hysterothylacium (Nematoda: Raphidascarididae) larvae in bogue (Boops boops L.) from the Aegean Sea, Turkey. Kafkas Üniversitesi Veteriner Fakültesi Dergisi, 24(4), 525-530.

Sneath, P.H.A., Sokal, R. (1973). Numerical taxonomy. W.H. Freeman and Co., San Francisco.

Soykan, O., İlkyaz, A.T., Metin, G., Kýnacigil, H.T.(2015). Growth and reproduction of Boops boops, Dentex macrophthalmus, Diplodus vulgaris, and Pagellus acarne (Actinopterygii: Perciformes: Sparidae) from east-central Aegean Sea, Turkey. Acta Ichthyologica et Piscatoria, 45(1), 39-55.

Stearns, S.C. (1983). A natural experiment in life-history evolution: field data on the introduction of mosquitofish (Gambusia affinis) to Hawaii. Evolution, 601-617.

Swain, D.P., Foote, C.J. (1999). Stocks and chameleons: the use of phenotypic variation in stock identification. Fisheries Research, 43(1-3), 113-128.

Templeman, W., Pitt, T.K. (1961). Vertebral numbers of redfish, Sebastes marinus (L.), in the North-West Atlantic, 1947-1954. ICES Rapp. Proc.-Verb. 150, 56-89.

Thabet, A., Abdel-Baki, A.A.S., Harrath, A.H., Mansour, L. (2019). Morphological and molecular aspects of Ceratomyxa ghannouchensis n. sp. and C. pallida Thélohan 1894 infecting the bogue, Boops boops (L.). Journal of Natural History, 53(9-10), 541-556.

Thomas, J.C. (1973). An analysis of commercial lobster (Homarus americanus) fishery along the coast of Maine 1966-70. U.S. Dep. Commer., NOAA Tech. Rep., NMFS-SSRF: 667: 57.

Todd, T.N., Smith, G.R., \& Cable, L.E. (1981). Environmental and genetic contributions to morphological differentiation in ciscoes (Coregoninae) of the Great 
Lakes. Canadian Journal of Fisheries and Aquatic Sciences, 38(1), 59-67.

Turan, C. (1999). A note on the examination of morphometric differentiation among fish populations: the truss system. Turkish Journal of Zoology, 23(3), 259-264.

Turan, C. (2000). Otolith shape and meristic analysis of Herring (Clupea harengus) in the northeast Atlantic. Archive of Fishery and Marine Research, 48(3), 283-295.

Turan, C. (2004). Stock identification of Mediterranean horse mackerel (Trachurus mediterraneus) using morphometric and meristic characters. ICES Journal of Marine Science, 61(5), 774-781.

Turan, C., Oral, M., Öztürk, B., Düzgüneş, E. (2006). Morphometric and meristic variation between stocks of Bluefish (Pomatomus saltatrix) in the Black, Marmara, Aegean and northeastern Mediterranean Seas. Fisheries Research, 79(1-2), 139-147.

Ünlü, E., Değer, D., Çiçek, T. (2012). Comparison of morphological and anatomical characters in two catfish species, Silurus triostegus Heckel, 1843 and Silurus glanis L., 1758 (Siluridae,
Siluriformes). North-Western Journal of Zoology, 8(1), 119-124.

Via, S., Gomulkiewicz, R., De Jong, G., Scheiner, S.M., Schlichting, C.D., Van Tienderen, P.H. (1995). Adaptive phenotypic plasticity: consensus and controversy. Trends in Ecology and Evolution, 10(5), 212-217.

Waldman, J.R. (2005). Stock Identification Methods. Academic Press, London.

Wimberger, P.H. (1992). Plasticity of fish body shape. The effects of diet, development, family and age in two species of Geophagus (Pisces: Cichlidae). Biological Journal of the Linnean Society, 45(3), 197-218.

Zaafrane, S., Maatouk, K., Akrout, F., Trabelsi, I., Drira, N. (2019). Spatio-temporal distribution of physicochemical and bacteriological parameters in the north area of Monastir bay, eastern coast of Tunisia. Arabian Journal of Geosciences, 12(6), 1-18.

Zrafi-Nouira, I., Khedir-Ghenim, Z., Zrafi, F., Bahri, R., Cheraeif, I., Rouabhia, M., Saidane-Mosbahi, D. (2008). Hydrocarbon pollution in the sediment from the Jarzouna-Bizerte coastal area of Tunisia (Mediterranean Sea). Bulletin of Environmental Contamination and Toxicology, 80(6), 566-572. 